[農化 第 43 巻，第 1 号, p. 55 59, 1969]

水稲種実を暗所で発芽させそ際のイノシトールリン酸の変化*

\author{
合沢文夫, 早川利郎, 渡辺鉦吉 \\ (新渴大学農学部農芸化学科生物化学教室)
}

昭和年 43 月 7 日 2 受理

\title{
Change of Inositol Phosphate in Rice Seed during \\ Germination in Dark
}

By Humio Kurasawa, Toshiro HaYakawa and Shokichi WaTANABE

Laboratory of Biological Chemistry, Faculty of Agriculture, Niigata University

The Changes of phosphorous compounds in the rice kernel during germination were followed. No net change was observed in total and acid soluble phosphate. Inositol phosphate showed a markedly rapid decrease while inorganic phosphate content increased during germination. The main component of inositol phosphate was found to be inositol hexaphosphate both before and after the germination.

Free inositol content per gram of the seed before germination was $0.04 \mathrm{mg}$, while after germination it reached a value of $0.55 \mathrm{mg}$. Total inositol, on the other hand, decreased from $1.885 \mathrm{mg}$ to $1.245 \mathrm{mg}$ during this period. Per cent of free inositol in total inositol before germination was 2.01 and it increased to 43.99 after germination.

(Received July 2, 1968)

\section{緒論}

イノシトールリン酸は植物界に広く分布している。禾 本科植物の種実の中ではリン酸の $80 \%$ はイノシトール リン酸の形で存在する.これらの植物では登熟期にデン プンが合成されるが，その際用いられたシン酸はイノシ トールリン酸として貯蔵される。一方，発芽期では代謝 に必要なリン酸はイノシトールリン酸から供給されるる のと思われる.

既報(1) において私どもはイノシトールが Schizosaccharomyces pombe を用いることにより定量さ机ること を認めた.

本報においては，水稲を暗所で発芽させた際，てノシ トールリン酸の变化について研究した。植物の発芽に伴 ライノシトールリン酸の変化についてはBurkholder ${ }^{(2)}$, Darbre (3) らの報告がある. Burkholder ${ }^{(2)}$ は大麦を5日 〜6 日発芽させるとイノシトールの含量は乾物 $1 \mathrm{~g}$ 中に $630 \mu \mathrm{g}$ から $1290 \mu \mathrm{g}$ に增加することを認めている.

Darbre ら (9) は大麦を発芽さ好をと，全イノシト一ルは

*水稻種実のミオイノシト一ル合成酔素に関する研究 (第 2 報) $\mathrm{g}$ 当り $2690 \mu \mathrm{g}$ が $2630 \mu \mathrm{g}$ と変化がなく，遊離イノシト 一ルは $85 \mu \mathrm{g}$ から $300 \mu \mathrm{g}$ に增加することを認めてい る.

以上のを5に，大麦の発芽によるイノシトールの含量 の変化についての実験はあるが，水稲種実の発芽に扣け るイノシトールリン酸, イノシトールの含量の变化につ いての研究はない。よって私たちは水稲を暗所で発芽さ せた際に敊ける粅中のリン酸化合物，およびイノシトー ルの含壆について㬰験したので報告する。

実験の方法むよび結果

柽を暗所で発芽させて, 各時期に発芽種子を採って実 験材料とし，これらの材料についてリン酸化合物の含量 の变化，イノシトールリン酸塩の形態怙よびイノシトー ルの含量の变化について実験した。

\section{1. 試料の調製}

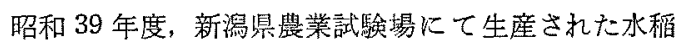
農林 43 号の䊀を用いた。粐を $0.1 \%$ 昇我で 20 分間殺 菌した後，蒸溜水で完全に洗浄した。この粐をシャーレ 中に播種し, 温度 $30^{\circ} \mathrm{C}$ の恒温器中にシャーレを入れて 発芽させた。播種直後，1日，3日，6日，9日，12日後 
に粉を取り出し，室温で通風乾燥後 50 メッシュに粉哗 した．聮水リン酸の入ったアブデルハルデン乾燥器で $80^{\circ} \mathrm{C}$ で隇死乾燥後, デシケーター中に保管して, 試料 とした.

\section{II. 発芽による粐重の減少}

シャーレに乾熱殺菌した脱脂綿を啔き，その中に衩を 約 $15 \mathrm{~g}$ (含水物)を播種し，発芽粐をそれぞれ取り出し， $105^{\circ} \mathrm{C}$ で乾燥して恒量として，粐重の減少の暳合を示し た。結果恃第 1 表のようである。

第 1 表 発芽日数と耀重の变化（無水物 $\mathrm{g}$ )

\begin{tabular}{lcrrrrr}
\hline 発䓔日数 & 播種直後 & 1 日後 & 3 日後 & 6 日後 & 9 日後 & 12 日㣪 \\
\hline 発芽前粐重 & 12.93 & 12.93 & 12.92 & 12.91 & 12.93 & 12.93 \\
発芽後粐 重 & 12.93 & 12.87 & 12.54 & 11.46 & 10.42 & 7.78 \\
粐重減少割合 $\%$ & 0 & 0.46 & 2.94 & 11.27 & 19.38 & 39.81 \\
100 粒 重 & 2.65 & 2.64 & 2.58 & 2.36 & 2.14 & 1.58 \\
\hline
\end{tabular}
测定した.
ボ中に硝酸マグネシウム溶液（95\% エチルアルコール に硝酸マグネシウムを飽和させる） $3 \mathrm{ml}$ を加竞，よく液 老浸し，最初低温它乾かした後 $400 \sim 600^{\circ} \mathrm{C}$ で灰化する。 $10 \mathrm{~N}$ 硫酸 $2 \mathrm{ml}$ を加克, $100 \mathrm{ml}$ に稀稂し，これより 10〜 $15 \mathrm{ml}$ を採り，イソブチルアルコール法 ${ }^{(4)}$ 以よって比色

フィチン態リン：リン脂質を抽出した残留物を用い る. 牫留物の入っている円筒濾紙を湯煎鍋上で溶剂を蒸 発させ，残留物をフラスコに移し， $2 \%$ 塩酸 $50 \sim 100 \mathrm{ml}$ を正確に加兄，振䔽機で 2 時間フィチ ンを抽出する. 後, 無死滤紙で濾過 し, 最初の部分を棄てた後 $20 \mathrm{ml}$ を採 る.フェノールフタレンを 1 滴加点, $5 \mathrm{~N} \mathrm{NaOH} 2 \mathrm{ml}$ 学加充, 次に $1 \mathrm{~N}$ $\mathrm{NaOH} \Leftarrow 1 \mathrm{~N} \mathrm{HCl}$ で中和する. 脱塩 水で $25 \mathrm{ml}$ に稀釈し，これに塩化鉄

\section{III. 発芽種子内のリン酸化合物の分画定量}

各リン酸化合物（全リン，酸可溶性リン，フィチン態 リン，無機リン，リン脂質態リン）の分画定量は，主に Ponsら (4)の方法を参考にして行なった

全リン：乾燥試料 $0.5 \sim 1 \mathrm{~g}$ (この場合リンの含量が $1.5 \mathrm{mg}$ を越克ないよ5にする）をケルダール分解瓶中 に入れ，これに濃硫酸 $3 \mathrm{ml}$ を加党て加熱する。さらに $30 \%$ 過酸化水素 $3 \sim 4$ 滴を加克て加熱する．分解後 100 $\mathrm{ml}$ に稀䐆し，これより $10 \sim 20 \mathrm{ml}$ 採り，還元モリブデ ン法(4)火よって比色测定する.

無機リン： 乾燥試料 500 〜 $600 \mathrm{mg}$ 亿冷却せる 0.75 $\mathrm{N}$ トリクロル醁酸 $25 \mathrm{ml}$ を加点, 約 1 洔間振盗抽出後, 無灰濾紙にて䲣過し，初めに出てくる濾液をのぞき，そ の後の濾液より $5 \sim 10 \mathrm{ml}$ を正確にとり，イソブキルア ルコール法(4) によって比色定量した。

酸可溶性リン：乾燥試料 $500 \sim 600 \mathrm{mg}$ に $0.75 \mathrm{~N}$ 卜

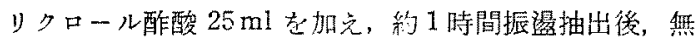

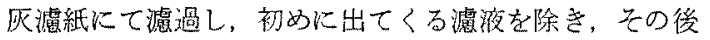
5〜10 ml を正確汇採り，全リン定量法汇準じて分解した のセ，無機リン法に準じて定量した。

リン脂啠態リン： 試料 $0.5 \sim 1.0 \mathrm{~g}$ をりクスレー脂 肪抽出器にてベンゼン・エチルアルコール混液 $60 \mathrm{ml}$ に て抽出する。抽出混液を蒸発させた後，95\%エチルア ルコール $10 \mathrm{ml} に て 2$ 回, さらに $70 \%$ エチルアルコー ルにて 2 回加熱しながら抽出物を磁製ルッボ中に流し落 す. 加熱によってアルコールを蒸発除去する，磁製ルッ ( $\mathrm{FeCl}_{3}$.6 $\mathrm{H}_{2} \mathrm{O} 15 \mathrm{~g}$ を $1 \mathrm{~N} \mathrm{HCl}$ に溶かして 11 とする) 5 $\mathrm{ml}$ を加克，よく摫找して湯煎鍋上で 15 分間煮沸す る. 冷水で 20 分間冷却後, 生じたフィチン鉄塩を 1,800 $\mathrm{rpm}$ で 20 分間遠心分離を行な5。沈溊は $10 \%$ 硫酸り 一ダを含む $0.6 \%$ 塩酸 $5 \mathrm{ml}$ で撹汼洗浄する．擋汼棒は $2 \mathrm{ml}$ の塩酸で洗浄する. 再び $1800 \mathrm{rpm}$ で 20 分間遠心

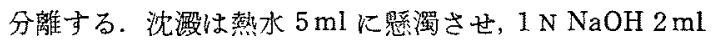

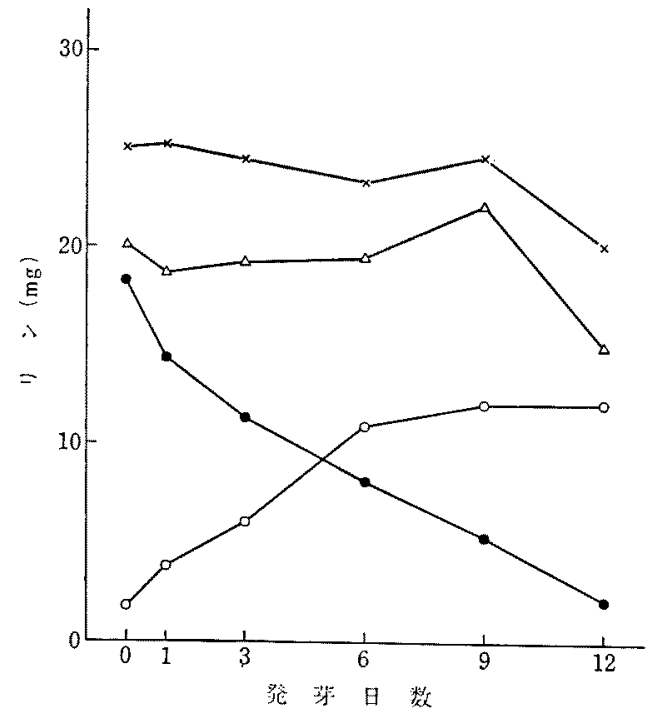

第 1 図発芽に伴5りン酸化合物の含量の变化

(乾重 $1 \mathrm{~g}$ 中)

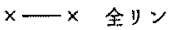
$\triangle-\triangle$ 酶溶性りン
O

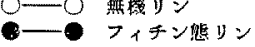


を加え， $100^{\circ} \mathrm{C}$ の湯浴中で時々摫䢁しながら加温する. 生ずる水酸化鉄は濾別する。濾液打よび水酸化鉄を熱水 $5 \mathrm{ml}$ で 3 回洗浄した洗液は合して、ケルダールのフラ スコに入れ，全リン定量法に準じて分解定量した。

発芽種子中の各種りン酸化合物の含量㹥第 1 図の上5 である。

全りン, 酸可溶性りンは各時期による含量の变化は, ほとんどなかったが、フィチン態リンは減少し，それに 伴って無機りンは増加していた.

\section{IV. 発芽の各時期におけるイノシトールリン酸の分画} 定量

発芽に伴ってフィチンリンは減少して, 無機リンは增 加していた．よって播種直後，1日，3日，6日，9日後 に粐を取り出し，室温で通風乾燥後 50 メッシュに粉細 し，イノシトールリン酸を抽出し，これらを Dowex 1 $\times 2(\mathrm{Cl}$ 型) に吸着させ, 塩酸の濃度を变克て溶出させ, イノシトールリン酸の形態について調ベた，イノシトー ルリン酸の分画，調製には永井(5) らの方法を参考にし た. 各発芽種子 (乾燥粉末) $50 \sim 80 \mathrm{~g}$ に $0.5 \mathrm{~N}$ 塩酸溶液 $500 \mathrm{ml}$ を加光, 室温で 4 時間振燳させ，イノシトール リン酸を抽出する，活性炭を少量添加して，セライトを 用いて濾過し，10\% 水酸化ナトリウム溶夜を用いて $\mathrm{pH}$ 8.0 に中和後 $25 \%$ 酷酸バリウムを沈測が生じなくなる まで加える．生じたバリウム塩は遠心分離によって集 め，バリウムイオンがなくなるまで水洗する，風乾後， $80^{\circ} \mathrm{C}$ で減圧乾燥した。得られた試料 $0.6 \sim 3 \mathrm{~g}$ を採り, $0.1 \mathrm{~N}$ 塩酸 $500 \mathrm{ml}$ 儿溶解後遠心分離し, 上澄液をDowex $1 \times 2(\mathrm{Cl}$ 型, $200 \sim 400 \times ッ シ ュ, 20 \mathrm{~cm} \times 1 \mathrm{~cm})$ に吸着 させた後，塩菜の反応がなくなるをで水洗した。っいで $0.1 ， 0.3 ， 0.5 ， 0.7 ， 1.0 \mathrm{~N}$ 程酸，招の抎の $250 \mathrm{ml}$ で溶 出した，流速は 10 分間に $25 \mathrm{ml}$ の割合で行なった。. 各 画分より $0.5 \mathrm{ml}$ を採り,過塩素酸 $0.9 \mathrm{ml}$ を加之, 60 分 間分解して，中村法(6)でリンを定量した．結果は第 2 図 のようである。

播種直後, 発芽 3 日目の試料は $1 \mathrm{~N}$ 塩酸溶出画分が得 られ，発芽6日，9日目の試料は $1 \mathrm{~N}$ 塩酸溶出画分が主 な成分ではあるが， $0.7 \mathrm{~N}$ 塩酸， $0.3 \mathrm{~N}$ 塩酸溶出画分が 僅かながら存在した．次に $1 \mathrm{~N}$ 塩酸溶出画分の分析を行 なった。すすなわわ，溶出画分は集めて減圧漲縮し，10\% 水酸化ナトリウム溶液を用いて，pH 8.0 亿調整後 $25 \%$ 酢酸バリウムを沈澱が生じなくなるまで加光，生じたパ リウム塩は遠心分離によって集め，バリウムイオンがな
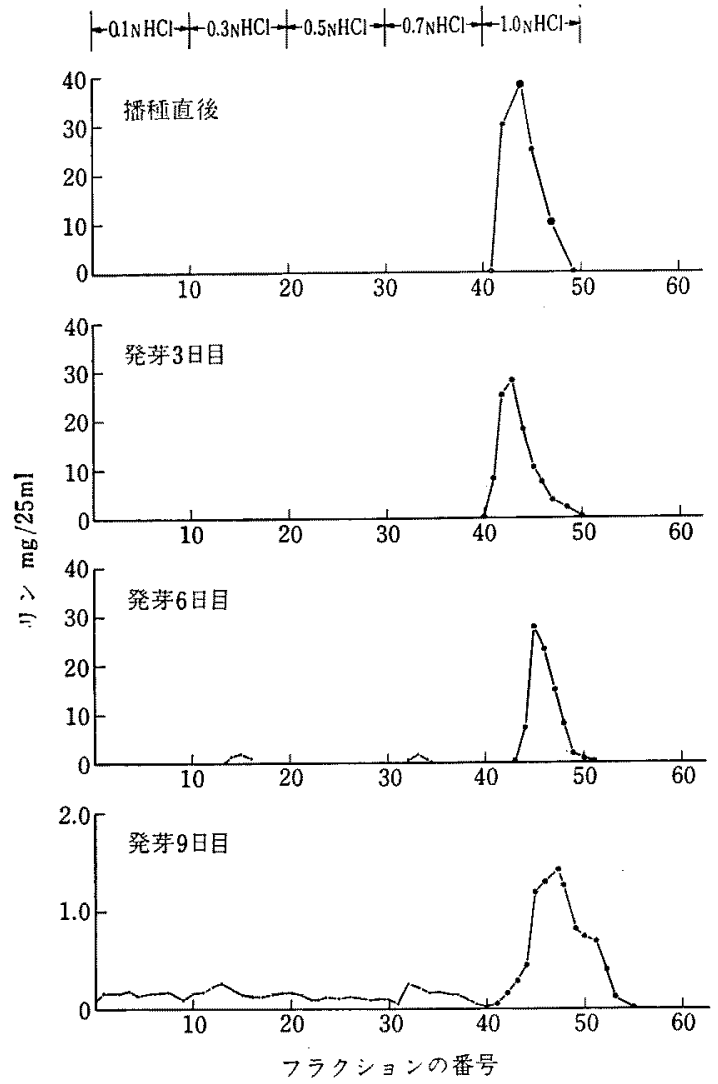

第2四発芽の各時期に扣けるイノシトール リン酸の分画定量

\begin{tabular}{|c|c|c|c|c|c|}
\hline \multirow{3}{*}{\multicolumn{2}{|c|}{ 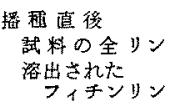 }} & & \multicolumn{3}{|l|}{ 発瑟 3 日目 } \\
\hline & & $172 \mathrm{mg}$ & 誈料 0 全 & $y ン$ & $121 \mathrm{mg}$ \\
\hline & & 170 & $\begin{array}{c}\text { 溶出された } \\
\text { フォキン }\end{array}$ & & $114 \mathrm{mg}$ \\
\hline 回 取 & 率 & $99 \%$ & 数 & 率 & $94 \%$ \\
\hline \multicolumn{2}{|l|}{ 発茅6日目 } & & \multicolumn{3}{|l|}{ 発茅9日罒 } \\
\hline 武相の全 & $y$ & $120 \mathrm{mg}$ & 路料の全 & リン & $20.0 \mathrm{mg}$ \\
\hline $\begin{array}{l}\text { 溶出された } \\
\text { フィテン }\end{array}$ & & $84 n$ & $\begin{array}{c}\text { 溶出された } \\
7 \neq \neq=\end{array}$ & & $13.6 \mathrm{mg}$ \\
\hline 無 榙 & 2 & $28 \mathrm{mg}$ & 無 機 ע & 2 & 4. $3 \mathrm{mg}$ \\
\hline
\end{tabular}

くなるまで水洗する，風乾後， $80^{\circ} \mathrm{C}$ で減圧乾燥する。得 られたパリウム塩は $0.1 \mathrm{~N}$ 塩酸で溶解後塩化第 2 鉄塩を 加克，上く攂找して湯前鍋上で 15 分間煮沸し，遠心分 離する． $0.2 \%$ 塩酸にて洗浄後水に蜸濁し， $1 \mathrm{~N}$ 水酸化 ナトリウム溶液を加え，よく筧找しながら煮沸し，生ず る水酸化鉄を濾過する．上く洗浄し，濾液に等量の土チ ルアルュールを加え，冷所に放置して結晶を析出させ る、得られたイノシトールリン酸のナトリウム塩はエチ ルアルニールにて脱水後，減压にて乾燥する．得られた $1 \mathrm{~N}$ 塩酸溶出画分の結晶 $40 \mathrm{mg}$ を採って，前報の力法に 
よってイノシトールの含量を，中村法的によってリンの 含量をそれぞれ定量した. $41 \mu$ moles のイノシトール， $251 \mu$ moles のリンの存在を認め, インシトールとリンの 割合はほぼ $1: 6$ であることを知りこの画分はイノシ トールヘキサフォスフェートであることを認めた。無機 リンは Dowexに吸着されず流失されるが一部 $0.1 \mathrm{~N}$ 塩 酸溶出画分に含まれていることを認めた。

V. 発芽種子内の遊離イノシトール，全イノシトール の含量の変化

発芽種子内の全イノシトール，遊離イノシトールの定 量を行なった，全イノシトールの定量用の試料の調製は Agranoff(7) らの方法を参考にした. 試料 $100 \mathrm{mg}$ に $6 \mathrm{~N}$ 塩酸 $3 \mathrm{ml}$ を加光，加王釜にて $134^{\circ} \mathrm{C} て ゙ 10$ 時間分解し た. 活性炭処理後吸引滤過する。濾液は濃縮乾固させて 脱塩酸を行ない，さらに少量の水に溶解して Amberlite IR-120 ( $\mathrm{H}$ 型)，括よび IRA-410 (OH 型) (ともに $10 \mathrm{ml})$ を通過後，濃縮して $100 \mathrm{ml}$ にして実駼試料とした。一 方，遊離イノシトール測定のため Darbre(3) の方法を参 考にして試料を調製した。試料 $1 \mathrm{~g} に 0.04 \mathrm{~N}$ 塩酸 $10 \mathrm{ml}$ を加え，2 分間ホモジナイザーにかけた後，遠心分離し て上澄液を得た。この操作を 4 回繰返し，上澄液を合し て濃縮後, Amberlite IR-120 (H 型)，怙よび IRA-410 ( $\mathrm{OH}$ 型)（ともに $10 \mathrm{ml}$ )を通過させて $100 \mathrm{ml}$ とした。 こ机らの試料から $1 \mathrm{ml}$ を採りこれ基礎培地 $1 \mathrm{ml}$ 加光，加压鉒中で $115^{\circ} \mathrm{C} て ゙ 10$ 分間隇菌する. 微生物定 量法は既報のイノシトール定量法と全く同様にして行な った、既報のイノシトールの定量には同じ濃度に稀积し た試料 3 本をとって測定し平均值を求めたが，本報告で は全イノシトールの測定の場合には段階稀釈 $(1,1 / 2$, 1/3) をし，遊離イノシトールの場合には段階濃縮 (1，2 倍，4倍）をした試料で測定して平均值を求めた、結果 は第 2 表のようである。

遊離イノシトールは発芽前には $1 \mathrm{~g}$ 中 $0.04 \mathrm{mg}$, 発芽 12 日目 $0.55 \mathrm{mg}$ 飞增加して招り, 全イノシトールは
$1.88 \mathrm{mg}$ が $1.25 \mathrm{mg}$ に減少していた. また遊離イノシト ートル/全イノシトールの割合は発芽前 $2 \%$ が発芽 12 日 目では $43.99 \%$ に增加した。

考察

大麦の発芽によるイノシトールの含量の变化について は Burkholder (2), Darbre(8) の研究がある. 水稲種実の 登熟期炕けるイノシトールリン酸の含量の変化につい ては浅田ら ${ }^{(8)}$ ，斉尾 ${ }^{(9)}$ の研究がある。私どもは水稲の発 芽期に括けるイノシトールリン酸, イノシトールの変化 について実験した．水稲種実索暗所で発芽させた際，フ ィチン態リン（イノシトールヘキサフォスフェート）は 滅少し、それに伴って無機リンは增加した。種実中に含 まれているリンの 80\% はフィチン態リンであるので， 発芽の際に代謝に用いられる大部分のリンはフィチンか ら供給されるものと考えられる。この実験では種実を暗 所で発芽させているのでリンは無機りンの形で検出され ているが，明所では無機りンは一部が再び有機りンに変 わり，代謝されるものと考完られる，次に発芽時にイ， シトールリン酸の形態を調べたのに，発芽の初期にはイ ノシトールーキサフォスフェートが検出され，その後， イノシトールーキサフォスフェートと無機リンが検出さ れ, さらに発芽後期には少量の $0.3 \mathrm{~N}, 0.7 \mathrm{~N}$ 塩酸溶出画 分が認められたが大部分はイノシトールーキサフォスフ ェートと無機リンであった. 発芽前に $1 \mathrm{~g}$ 中の遊離イノ

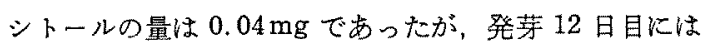
$0.55 \mathrm{mg}$ に增加していた. 全イノシトールは発芽前は $1.88 \mathrm{mg}$ であったが，発芽 12 日目は $1.25 \mathrm{mg}$ に減少し ていた.

\section{結論}

水稲農林 43 号を暗所で約 12 日発芽させた際に、リン 酸化合物の含量の変化について実験した，全りン，酸可 溶性リンは各時期においてあまり含量の变化はなかった が、フィチンリンは減少し，それに伴って無機リンは增 加していた.

第 2 表 発芽種子に含まれる遊離イノシトール, 全イノシトールの含量の変化

\begin{tabular}{|c|c|c|c|c|c|c|c|}
\hline \multicolumn{2}{|c|}{ イノシトールの含量 発 芽 日 数 } & 発芽前 & $\begin{array}{l}\text { 発芽後 } \\
1 \text { 日目 }\end{array}$ & 発著 & $\begin{array}{l}\text { 発 } \text { 芽 } \\
6 \text { 苜 }\end{array}$ & $\begin{array}{l}\text { 発 芽 } \\
9 \text { 日首 }\end{array}$ & $\begin{array}{l}\text { 発 } \text { 芽 } \\
12 \text { 日目 }\end{array}$ \\
\hline \multirow{3}{*}{$\begin{array}{c}\text { 乾重 } 1 \mathrm{~g} \text { 中の含量 } \\
(\mathrm{mg})\end{array}$} & 遊離イノシトール & 0.04 & 0.17 & 0.31 & 0.48 & 0.54 & 0.55 \\
\hline & 全イノシトートル & 1.88 & 1.72 & 1.75 & 1.66 & 1.58 & 1.25 \\
\hline & $\frac{\text { 遊離イノシトール }}{\text { 全イノシール }} \%$ & 2.01 & 10.09 & 17.50 & 28.99 & 34.13 & 43.99 \\
\hline $100 \begin{array}{c}\text { 粒 中の含量 } \\
(\mathrm{mg})\end{array}$ & $\begin{array}{l}\text { 遊離インシトール } \\
\text { 全イイシール }\end{array}$ & $\begin{array}{l}0.10 \\
5.01\end{array}$ & $\begin{array}{l}0.54 \\
4.54\end{array}$ & $\begin{array}{l}0.80 \\
4.55\end{array}$ & $\begin{array}{l}1.13 \\
3.91\end{array}$ & $\begin{array}{l}1.16 \\
3.39\end{array}$ & $\begin{array}{l}0.88 \\
1.99\end{array}$ \\
\hline
\end{tabular}


発芽に伴ら、イノシトールリン酸の形態を調査したの に，発芽前ははとえどイノシトールへキサリン酸であっ たが，発芽によって無機リンが現われた．しかしイノシ トールリン酸は大部分がイノシトールヘキサリン酸であ った。

発芽に伴 5、イノシトールの含量の変化については, $1 \mathrm{~g}$ 中の遊離イノシトールは発芽前には $0.04 \mathrm{mg}$ のの が発芽 12 日目では $0.55 \mathrm{mg}$ に增加していた，全イノシ トールは発芽前に $1.88 \mathrm{mg}$ ののが発芽 12 日目では $1.25 \mathrm{mg}$ に減少していた，遊離イノシトール/全イノシ トールの割合は発芽前には $2.01 \%$ であったものが，発 芽 12 日目では $43.99 \%$ に増加していた。
（1）會沢交夫，早川利郎，金内喜昭：乘化，42，587 (1969).

(2) P. R. Burkholder : Science, 97, 562 (1943).

(3) A. Darbre and F. W. Norris : Biochem. J., 64, 441 (1956).

(4) W. A. Pons, Jr., M. F. Stansbury and C. L. Hoffpauir: J. A. O. A. C., 36, 492 (1953).

(5) Y. Nagai and S. Funahashi : Agr. Biol. Chem,, 26, 794 (1962).

（6）中村道徳：苌化，24，1 (1950).

(7) B. W. Agranoff, R. M. Bradley and R. O. Brady : J. Biol. Chem., 223, 1077 (1958).

(8) K. Asada and Z. Kasai : Plant Cell Physiol., 3, 397 (1962).

(9) K. Saio: ibid., 5, 393 (1964). 